\title{
The Renaissance of the Corsican Confraternities and their Musical Negotiations
}

DOI:

10.1093/oxfordhb/9780199859993.013.002

\section{Document Version}

Accepted author manuscript

Link to publication record in Manchester Research Explorer

\section{Citation for published version (APA):}

Bithell, C. (2016). The Renaissance of the Corsican Confraternities and their Musical Negotiations. In J. Dueck, \& S. Reily (Eds.), The Oxford Handbook of Music and World Christianities (pp. 293-314). (Oxford Handbooks).

Oxford University Press. https://doi.org/10.1093/oxfordhb/9780199859993.013.002

\section{Published in:}

The Oxford Handbook of Music and World Christianities

\section{Citing this paper}

Please note that where the full-text provided on Manchester Research Explorer is the Author Accepted Manuscript or Proof version this may differ from the final Published version. If citing, it is advised that you check and use the publisher's definitive version.

\section{General rights}

Copyright and moral rights for the publications made accessible in the Research Explorer are retained by the authors and/or other copyright owners and it is a condition of accessing publications that users recognise and abide by the legal requirements associated with these rights.

\section{Takedown policy}

If you believe that this document breaches copyright please refer to the University of Manchester's Takedown Procedures [http://man.ac.uk/04Y6Bo] or contact uml.scholarlycommunications@manchester.ac.uk providing relevant details, so we can investigate your claim.

\section{OPEN ACCESS}


The Renaissance of the Corsican Confraternities and their Musical Negotiations

\section{Caroline Bithell}

University of Manchester, UK

NOTE: This is a post-print (Author's Accepted Manuscript) for:

'The Renaissance of the Corsican Confraternities and their Musical Negotiations'. In The Oxford Handbook of Music and World Christianities, ed. Suzel Ana Reily and Jonathan Dueck, pp. 293-314. New York: Oxford University Press, 2016. (First published on Oxford Handbooks Online, Dec 2013).

One of the most intriguing developments in Corsican religious and cultural life in the late twentieth and early twenty-first centuries was the revitalization of the confraternities (Roman Catholic lay brotherhoods). This chapter explores the conditions and motivations that underpinned this phenomenon and offers an insight into the part played by the confraternities in the contemporary church and in modern-day Corsican society. The polyphonic song repertories that the brotherhoods have preserved through the centuries remain central to their identity and play a pivotal role as they negotiate their relationships with other actors in the religious arena. In the decade from 1994 to 2004, I had regular contact with several confraternities in different parts of the island and so was able to witness at first hand the part played by music in the demarcation of sacred spaces, both physical and acoustic, during a critical period of transition. ${ }^{\mathrm{i}}$

I begin with a brief history of the confraternities in Corsica, with particular reference to changes in their status in relation to the church authorities, their musical practices, and their 
broader social and political function. I then examine in greater detail the reasons behind their recent revival and, with the aid of a selection of short case studies, describe the processes involved in reintroducing the confraternities into the life of both church and community and reacquiring semi-forgotten musical repertories. The confraternities have always preserved a degree of autonomy vis-à-vis the ecclesiastical authorities and in the 1990 s and early 2000 s this was exercised most keenly in contests over musical style. I examine the dynamics of the various oppositions - aesthetic, ideological, linguistic, and gender-related - that the confraternities have had to engage with as they have sought to redefine their position in the soundscape of the contemporary church.

The play of power that manifests itself in disputes over sounds and spaces in this case involves not different religions but different actors on the Christian stage, with many of the ideological conflicts resulting from the reforms of the Second Vatican Council continuing to be played out in popular religious practice. I show how, from the perspective of the confraternities, musical expression — even within the religious sphere — is intimately bound up with notions of an authentic "local" sound and with questions of ownership of local spaces. The study also reveals the influence of amateur, grass-roots initiatives in determining socioreligious and musical directions. Finally, the musical practices of the confraternities emerge as a crucial attraction for young people, offering them a viable route to becoming actors in their immediate community while expressing their new-found sense of national or ethnic identity and their commitment to the island's heritage.

$<1>$ A Postcard from Corsica

Picture Calvi, with its modest population of no more than five thousand, looking out to sea from its vantage point in the northwest corner of the island. With its nearby airport and its 
unlikely status as Corsica's third largest port, the town serves as one of the main points of arrival for the summer visitor to the island. Clambering around the cobbled alleyways of the vertiginous citadel with its tall granite buildings, one catches sudden glimpses of shimmering blue sea and a vast bay that is the stuff of dreams, its white sandy shores fringed by forests of Mediterranean pine and brooded over by layer upon layer of towering crags, still glistening with the remnants of the winter snows as the heat starts to build on the coast below. Huge ferries from France pull up incongruously at a tiny quay directly beside the citadel. Prickly pear and fig trees thrive on the rocky outcrop out of which the buildings themselves seem to grow. At the top of the pile, like the cherry on a cake, sits the thirteenth-century Cathedral of St. Jean Baptiste. A stone's throw away, its entrance hidden in one of the narrow lanes, is the four-storey Oratory of St. Antoine, home of the confrérie of St. Antoine Abbé/San' Antonu Abbate and founded in the latter part of the fourteenth century. This is the Haute Ville, whose origins date back to 1268, not long after which Calvi became established as a Genoese stronghold—hence the town's not entirely implausible claim to being the birthplace of Christopher Columbus. Down below is the Basse Ville, its ancient parish church of Ste. Marie Majeure/Santa Maria Maggiore_-likewise dating back to the thirteenth century and home to the confrérie of St. Erasme, founded in 1825-now tightly hemmed in by the restaurants and boutiques that have mushroomed in more recent times to cater for the summer tourists. During Holy Week, on patron saints' days and for other major festivals such as the Assumption or All Souls, the town provides a dramatic setting for a series of processional comings and goings by its two confraternities. Clad in their long white habits and colored capes (grey for St. Antoine, reddish-brown trimmed with gold for St. Erasme, and deep crimson for the prieurs) and bearing an assortment of crosses, statues, lanterns, and maces, the confrères weave their way through the streets intoning the songs that have been handed 
down from generation to generation (fig. 1). [INSERT OWM COMPUTER ICON HERE plates 1,2 , and 3]

\section{[INSERT FIGURE 1 HERE]}

It was in Calvi that I had my first encounter with the confraternities, having gone there in March 1994 with the specific aim of documenting the rituals of Holy Week. I was able to witness the full cycle of offices, masses, and processions, including the Office of the Tenebrae sung by the confréries in the oratory on Wednesday evening; the ritual washing of the feet of twelve confréres by their prieur during solemn mass on Maundy Thursday; the blessing of the canistrelli (the large, flat, circular cakes with a hole in the middle, pungent with fennel and aniseed, that are baked specially for Holy Week); Good Friday's early morning cerca procession (recalling Mary's search for her lost son), wending its way from the oratory down to Ste. Marie in the lower town, on to the tiny chapel of Notre Dame de Lorette, then back up to the cathedral in the citadel before finally returning to the oratory; the equally circuitous Friday evening procession punctuated by four enactments of the granitula (fig. 2) - a double spiral formation, replete with the symbolism of death and rebirth, traced by the confréries carrying the statue of the mourning Virgin and the figure of the dead Christ on a bier covered with white carnations, and accompanied by three penitents in white cagoules, their faces covered and their feet bare, each bearing a heavy cross; the blessing of the new fire and the baptismal water on the small stone terrace beside the cathedral on Saturday night; the masses to celebrate the resurrection on Saturday night and Sunday morning; the procession of Notre Dame du Saint Rosaire on Easter Monday, when at a spot on the edge of the citadel, high above the sea, the statue of the Virgin is held aloft to the four directions, followed by mass at the cathedral; and finally the blessing of the houses by the priest and two Franciscan monks, each accompanied by a small boy carrying an aspergillum (holy water sprinkler). 
Each stage of this ritual cycle unfolds to the rhythm of the songs that seem to stitch the days together. Perhaps you can catch the strains of "Presso il Legno," "Teco Diletta Madre," or "Stellatevi in Pianto" as the Good Friday procession approaches? Perhaps you will join the crowd as it squeezes inside the cathedral to hear the confrères sing the magnificent "Atto di Contrizione" as they kneel before the statue of Mary with her dead son laid out at her feet? It may take a while for your ears to adjust to resonances that, at times, seem to emanate from another age (some of the songs are believed by the older singers to date from the fourteenth century). A solo, unaccompanied male voice with deep, rich sonorities sets out the opening line in its own time, before this is taken up and harmonized by the whole company. Thirds that shift unexpectedly from minor to major add brightness and tension, until the line comes to rest on the distinctive tierce de Picardie with which almost all of Corsica's traditional polyphonic songs end. On Easter Monday this same space will be filled with very different sonorities when the mass is sung by the women's choir, joined by just three or four of the confrères and accompanied by the organ. French texts sung in unison to the modern, Gregorian-style melodies that today can be heard in Roman Catholic churches throughout mainland France give way to an Alleluia set to the tune of "Michael Row the Boat Ashore." The majority of the confrères are now seated out of sight behind the altar and their voices are heard only at the end of the service, when they once again take their place on their knees around the statue of the Virgin to lead the singing of the national hymn, "Dio vi Salvi Regina." If you're lucky, you may be invited to return with them to their oratory, where the table that normally serves as altar is loaded with bottles of sweet white wine and piles of canistrelli. The air is now bright with animated voices, happy that the rituals of the past week have been successfully concluded and a new year has begun. There is an atmosphere of “school's out": Easter is over. 
In the course of my conversations with the late Alphonse Francheschi (then gouverneur of St. Antoine) and later more extensive interviews with the young prieur, Pierre Bertoni, I grew increasingly fascinated by the confraternities and the world-view that they represented. It also became apparent that, while the traditions described here may have been part of the fabric of life in Calvi for centuries, in certain other parts of the island the confraternities, together with their songs and rituals, had long since fallen into abeyance but were at this very moment in the process of being revived.

$<1>$ A Brief History of the Confraternities in Corsica

Referred to in French as la confrérie and in Corsican as a cunfraternità or cunfraterna, the confraternity is an association of laics in the service of Roman Catholic Church. ${ }^{\text {ii }}$ Confraternities have been present in Corsica since at least the fourteenth century. For the greater part of their history, they have functioned as a popular, democratic institution with a strong local identity. Unlike the priest, who often comes from outside the community and is further set apart by both education and allegiance, the confrères (cunfratelli) are essentially "of the people" and, while formally under the jurisdiction of the bishop and ultimately answerable to Rome, they have always enjoyed an intriguing degree of autonomy.

Each confrérie is dedicated to a saint, devotion, or mystery. Historically, some brotherhoods brought together men employed in a particular profession, for example, St. Erasmus for fishermen and St. Joseph for carpenters. The majority of the Corsican confréries, however, were either penitents or caritatives, whose mission was to exercise charity and compassion and to care for the material as well as spiritual wellbeing of the community. In this respect they fulfilled an important social function: they provided for widows and orphans, cared for the sick, visited prisoners, and comforted the condemned and dying. They also acted 
as intermediaries in disputes and family vendettas. In addition, they played a central role in funerary rites. At the level of the individual, confrérie membership was intended to encourage personal devoutness and spiritual discipline.

By the beginning of the seventeenth century, almost every village had a confrérie and in the main towns there were several, counting among their members the majority of men in the neighborhood. Some were open to both sexes, but with the participation of female members being more restricted. There were also separate confréries or associations of women (often widows), but these were of a very different nature and remained more firmly under the control of the curates. The majority of confraternities active in Corsica at the end of the twentieth century were exclusively male.

The legendary autonomy of the Corsican confréries was aided by the fact that most had their own meeting place. While some were accorded a small side chapel or altar within the parish church, it was more usual for the confrérie to have its own separate building, known as the casazza (or casaccia; in French, la confrérie); a handful of these had the status of an oratory (oratorio). In many Corsican villages today, two separate church buildings sit side by side or face one another across a central square: the official village church, under the control of the priest, and the casazza, which the priest may enter only by invitation. Normally, the confrères would be required to attend the main church for Sunday mass, while the casazza was used for the singing of the offices and, less formally, for rehearsals, the preparation of processional objects, and meetings relating to the business of the confrérie. ${ }^{\text {iii }}$ The funds of the confréries are derived primarily from the annual subscriptions paid by their members. In the past, this income was supplemented by fines for disobedience and, in some cases, by the sale of candles or the renting out of land. ${ }^{\text {iv }}$ The financial independence of the confréries is another factor that has contributed to their autonomy vis-à-vis the ecclesiastical authorities. 
The confrérie is led by a prieur (piore), supported by a sous-prieur (sottu-piore). The prieur is responsible for organisational matters and for encouraging and supporting other members; in the past he would also enforce the rules regarding attendance and impose fines and other sanctions on those whose behavior was found lacking. Some confréries have a separate master of ceremonies - referred to in some places as a chancelier (cancillieru) and in Calvi as gouverneur — who has special responsibilities relating to the organization of processions and/or singing. Broadly speaking, the musical repertories of the confraternities have traditionally included the offices, Latin liturgical hymns (such as the "Te Deum," “Tantum Ergo," and "Vexilla Regis"), processional and devotional songs (often in old Tuscan), and song cycles for Holy Week.

As in other parts of Europe, the Corsican confraternities enjoyed their golden age in the period directly following the Council of Trent (1545-1563), which harnessed the energies of what it termed "associations of laics with a pious vocation" to play a crucial role in popular mission activity. The Council also encouraged the external manifestation of faith through spectacular processions and in this, too, the confraternities were to play a vital part. While the main liturgical processions were presided over by the priests, for other occasions the organization fell to the confréries and in this case the clergy were present, if at all, only as members of the congregation (Römer 1983: 36). To give an example of the scale of such activity, the original statutes of the confraternity of Santa Croce in the village of Speloncato in the Balagne (established in 1632) detail twenty-five compulsory processions per year. ${ }^{\mathrm{V}}$

Corsica in the eighteenth century remained resolutely Tridentine, although the passage from Genoese to French rule following the 1768 Treaty of Versailles set the scene for a slow integration into the Gallic church. Immediately prior to the French Revolution, the island had at least 200 active confraternities, most of which continued to function despite the interdiction of 1792. By the nineteenth century, however, the degree of autonomy they enjoyed had 
become a cause of serious concern to the ecclesiastical authorities, who accused them of fuelling breaches between the people and the clergy, and of nourishing popular superstition and fanaticism through their colourful cults while the more sober and educational offerings of the parish church were regarded with relative indifference (De Moro 2001: 286; Römer 1983: 55). Römer cites a sousprefet of Calvi complaining in 1822 that the Corsicans' fondness for "bizarre observances" and the "grotesque" costumes of the penitents was so great that even the most insignificant confrérie chapel was preferred to the parish church. There are suggestions that some confréries were effectively closed down by the authorities. A newspaper report on the confrérie of Bastelica, for example, notes that it had been officially suppressed by the law of $10^{\text {th }}$ August 1792 and had subsequently reappeared after a concordat of 1801, although in the intervening years it had continued to function clandestinely (CorseMatin, 24 April 1993).

Other brotherhoods at this time fell victim to increasing secularization, becoming little more than mutual societies concerned more with the material care of their members than with singing the offices (Casta 2001: 77). In the twentieth century the confraternities entered a period of unprecedented decline. Like many other aspects of traditional life, they suffered from the devastating demographic, social, and cultural upheaval that resulted from the two World Wars. Membership was decimated as a result of both loss of life and rampant emigration. Recruitment from among the younger generation reached an all-time low-a circumstance that also weakened the confraternities' economic independence. Many were subsequently disbanded or entered a period of hibernation from which they were not to emerge for several decades.

A growing problem with the level of insular recruitment to the priesthood also became acute after the First World War and from the 1930s priests were sent over to Corsica from mainland France and other parts of Europe, in particular Poland (Casta 2001: 80). Relations 
between the confraternities and the clergy became ever more strained as many of the former resisted the modernizing tendencies of the latter. Polacci (1997) tells of a visit to the Carbuccia confrérie by the Bishop of Ajaccio in 1931, at a time when serious quarrels had already blighted the relationship between the confrérie and the village priest. While focusing in particular on matters relating to the organization of funerals, the dispute also encompassed other rites and appeared to have at its core the fact that the new generation of priests educated in the "French school" had begun to introduce French canticles that did not find favour with the local populace. Similar disputes were, it seems, repeated throughout the island.

Those confraternities that managed to remain active into the 1960 s were further destabilized by the reforms of the Second Vatican Council (1962-65). Whereas the displacement of Latin by the vernacular was welcomed in many places, Corsica found itself in the position of seeing a language from which it claimed direct descent (some Corsicans today see themselves as speaking "modern Latin") ousted in favour of French, which was viewed by many as a foreign language imposed by a quasi-colonial power. With the Latin language went a large part of the confraternities' song repertories, now replaced by modern French canticles sung by newly established women's choirs accompanied on the harmonium. At the same time, patron saints' day celebrations and processions were played down in favour of an emphasis on individual devotion - faith without the trappings - that again served to sideline the confraternities. By the 1970s, only a handful — as few as ten, according to one estimatewere still active at any meaningful level.

Starting in the 1980s, however, a number of impulses came together to breathe new life into the brotherhoods, and by the year 2000 around fifty had been resurrected. This trend continued in the years that followed, with newspaper reports on Holy Week processions and saints' day celebrations never failing to comment on the notable increase in attendance, especially among young people. 
$<1>$ The Musical Repertories of the Confraternities

Singing occupies a central place in the activities of many of these revitalized brotherhoods. In particular, it is often members of the newly revived confréries who sing the characteristic three-part paghjella-style settings of the Latin mass that now constitute one of the hallmarks of Corsica's musical heritage — the messe des vivants, sung for feast days and sometimes ordinary Sundays, and the messe des morts or requiem mass. These settings, preserved only in oral tradition, are often unique to a single village and may therefore be referred to as the versu of that village. Stylistically, they have much in common with the secular paghjella, most notably staggered voice entries with the middle voice leading, untempered intervals, metrical flexibility, and melismatic development. Traditionally, they are sung with just one voice to each part, although the bass may be doubled; in some cases different trios of singers might alternate (taking turns, for example, to sing the successive iterations of the Kyrie, Sanctus, or Agnus Dei).

Any attempt to view the association of the confréries with the singing of the mass as a longstanding tradition is, however, problematic. The most comprehensive survey and analysis of liturgical and paraliturgical musical repertories on the island, including an introductory account of the history and practices of the confraternities, can be found in Markus Römer's book, Schriftliche und mündliche Traditionen geistlicher Gesänge auf Korsika (1983). ${ }^{\mathrm{vi}}$ Here, Römer warns of the need for circumspection in making assumptions about the extent of the confrérie's musical involvement in past times, especially with respect to their role in the main liturgical services presided over by the priest. Certainly it would seem that, in the early stages of their existence, the confréries would have played a more limited part in these services than many did at the time of my own research. In the thirteenth century, it was not usual practice 
for laymen to play an active role in the liturgy. Marcel Pérès claims that, nonetheless, from the end of the fourteenth century, "In the villages, some brothers would act as cantors for the Sunday mass. They would sing the ordinary of the mass, namely the Kyrie, Gloria, Sanctus and the Agnus Dei, whereas the songs of the proper of the mass . . were sung by the clergy" (Pérès 1997: 3). Moving forward to the sixteenth and seventeenth centuries, Römer draws attention to reports and edicts which make reference to the obligation of the priests to sing during the mass and the offices, some (e.g. the prescriptions of the Synod of Bastia in 1657) stating quite explicitly that the role of the laics is to listen (Römer 1983: 26, 1996: 34-5). According to statutes dating from this time, the main responsibility of the confrères was to celebrate the offices in the casazza: that is, the Office of the Holy Virgin, the Office of the Dead, and the Offices of Holy Week. Even here, there is evidence to suggest that not all members of the confrérie sang, with accounts telling of how some confrères would stand outside the cazassa talking and creating disturbances while a more select group sang the office inside (Römer 1983: 38-9).

Meanwhile, Pérès emphasises the vital role played by the confraternities, post-Trent, as intermediaries in spreading the new Franciscan style of plainchant to the people (Pérès 1996: 10). ${ }^{\text {vii }}$ Römer posits that little can be known of the extent of direct contact between the confraternities and Franciscan monks, ultimately concluding that "in the total corpus of Corsican sacred songs, those pieces that can be traced back directly to Franciscan sources occupy a very small place in numerical terms" (Römer 1983: 266). He refers nonetheless to a seventeenth-century document that indicates that the confréries could not sing together with the secular clerics but could do so with the monks (ibid: 38). For Römer, the points of contact between the surviving repertoires of the confréries and those of the Fransciscan convents are strongest with respect to polyvocal psalmody in faux-bourdon style (1996: 34). He points out that, significantly, Alexander Sauli (Bishop of the Corsican diocese of Aleria from 1570 to 
1591) was a close friend of Charles Borromeo (Archbishop of Milan from 1566 to 1584). ${ }^{\text {vii }}$ Borromeo was a particularly influential figure in the Counter-Reformation and an energetic promoter of falsobordone; it might therefore be conjectured that Corsica would have been one of the beneficiaries of his efforts in this sphere (Römer 1996: 64). Römer believes that the laude, which took the form of Italian texts set to well-known melodies, together with popular Continental songs such as "Perdono Mio Dio," "Piangi, Piangi Peccatore," and "L'Orme Sanguine," were also introduced by Franciscan monks and travelling missionaries from the mainland and owed their widespread popularity in Corsica to their inclusion in the Lira Sacra, a church song book whose first edition was to be published in Bastia in 1848 (Römer 1983: 46). Insular poets soon began composing their own lodi to add to the repertoire of the local confréries. The lodi of Alessandro Petrignani, composed in the village of Venzolasca at the beginning of the nineteenth century but in a two-part musical style that has features dating from the thirteenth to fifteenth centuries, are a notable example; these are still sung by members of the confrérie of Santa Croce on Good Friday.

With respect to the musical controversies that emerged in the nineteenth century, Pérès sees the confraternities as representing a middle way between, on the one hand, those who wished to restore the tradition of Gregorian chant in the style found in manuscripts of the tenth and eleventh centuries and promote Palestrina-style polyphony, and, on the other, those drawn to a new style strongly influenced by symphonic music and opera (Pérès 1996: 8-9). The confréries continued to practice a style of music that bore the imprint of sixteenth, seventeenth, and eighteenth century aesthetics and found little favour with the church authorities of the day. For this reason, the Corsican repertories occupy a particularly significant position for Pérès as living survivals that turn a mirror on past traditions and may therefore provide the key to unanswered questions of performance practice as well as serving as "one of the best preserved witnesses of the catholic vocal traditions" (Pérès 1997: 3). 
$<1>$ The Revitalisation of the Confraternities: Rationale and Process

As suggested by the foregoing summary, the confréries have always shared sacred spaces, both physical and acoustic, with other actors in the religious rites, and the nature and degree of their involvement has changed over time in response to historical events as well as ecclesiastical reforms. At the same time, the majority maintained their own properties independently of the church and this allowed them the freedom to continue those practices that had always taken place without the priest's presence. In the process, they developed distinctive singing styles and interpretations such that, in past times, the village to which a confrérie belonged might be deduced from its singing. This resulted in a close identification of the confraternities with their immediate localities: they formed part of the everyday soundscape and thus the cultural heritage that is intimately bound up with the identity of the individual.

It was in large part this strong association with a sense of local identity and with collective memories of an affective order that lay behind initiatives to revive individual confraternities - initiatives that came from the "grass roots" and not from the church authorities. As Boissevain and others have noted, one of the more surprising by-products of increased secularization, industrialization, urbanization, and mobility has been a startling increase in local festivities and public rituals since the 1970s (see e.g. Boissevain 1992). Reports from across Europe indicate a concomitant growth in popular religious activity. In Corsica, the decade of the 1970s marked a critical turning point in the cultural and political life of the island. The late 1960s had seen the resurgence of the autonomist movement that heralded a broader consciousness-raising with regard to questions of cultural identity. This inspired a new enthusiasm on the part of young people for all things Corsican, including those 
aspects of traditional life that, not long before, had been rejected as outmoded or irrelevant. Tradition and heritage (patrimoine) were now reified as the embodiment of "the Corsican soul." A plethora of cultural associations appeared (constituted according to a French law of 1901), operating for the most part as small community endeavours run by amateur enthusiasts. Some began by focusing on the material restoration of organs, church bells, and statues. As part of their desire to reanimate village life, they then turned their attention to reviving patron saints' day festivities. This created a more pressing need for a confraternity to lead the processions and provide other ritual ingredients. Traditional music was central to the broader movement of cultural reclamation or riacquistu, with the three-part paghjella being adopted as the sonic emblem of the afore-mentioned "Corsican soul." The polyphonic repertories of the brotherhoods were therefore particularly prized.

The process of resurrecting a confrérie is, technically speaking, relatively uncomplicated if, rather than having been formally dissolved, it has simply lain dormant while continuing to have a legal existence. It is not uncommon to find cases where, even though a confrérie had to all intents and purposes ceased to operate in the 1940s, accounts had continued to be kept up to the 1970s (the main entries usually relating to electricity bills for the casazza). The first step towards reconstitution is to establish a viable membership base that is representative of the village as a whole, including men of different ages, backgrounds, and professions, and that promises long-term stability. The next step is to obtain the support of the local curate, who in turn presents the request to the Bishop. Once the new statutes have been approved, the confrérie may be officially re-launched.

Picking up the threads of the confrérie's former activities is less straightforward. The task of reinstating musical repertories that were preserved only in the memories of individuals inevitably presents a far greater challenge than that of repairing an organ or a bell. In some places, a sole cantor had kept parts of the repertory alive after the confrérie had disbanded. 
Where the rejuvenation was initiated by members of the younger generation, these individuals — by now in retirement and often ailing — were sought out as priceless repositories of the local heritage and recordings were made of all that they could remember. In other places, the revival process was set in motion by former confraternity members returning to their birthplace after a career on the Continent to find the local confrérie in a state of neglect. Drawing primarily on their own memories, they then set about transmitting the repertory to the younger men in the village.

In cases where there was no longer any trace of local practices, materials were initially borrowed from neighbouring villages or even further afield, often with the active support of those whose traditions had been better preserved. A new trend of gathering together confréries from all over the island for major feasts also facilitated the exchange of musical material, with those whose local repertory was somewhat thin being given "models" by other confréries to supplement the items they may have "borrowed" from recordings. [INSERT OWM COMPUTER ICON HERE -plate 4]

In other instances again, members of the semi-professional performing groups that had formed on the crest of the riacquistu were called upon to assist in the establishment of a new confrérie on the assumption that, as experienced singers, they would be able to teach the others to sing. Many of these groups had already set up informal scole di cantu ("singing schools") where they taught traditional songs, including — or in some cases primarily — the mass. This also meant that in some villages a group of young people had already begun to sing the mass and this then provided a foundation on which the confrérie could build, even if the mass itself had not previously been part of the confrérie's domain. The mass in question was, more often than not, that of either Rusio or Sermano. In these two small villages close to the center of the island, the old paghjella-style mass settings had continued to be sung by extended family ensembles without a break in the natural chain of transmission. They were 
also available on recordings, which made them accessible to singers in different parts of the island. After learning the mass of Rusio or Sermano, many singers were inspired to search for traces of their own village mass, thereafter moving on to other parts of the liturgy. This has resulted in an extraordinary grassroots movement engaged in musical archaeology and reconstruction across the island.

In the churches, meanwhile, the places vacated by the outlawed or abandoned confréries had long since been filled by others, most often the women's choirs put in place by the priests to sing the new approved repertory in French. In making a bid for their place in the church to be reinstated, the confréries therefore often found themselves entering into confrontations not only over musical aesthetics but also over matters of language and gender. Furthermore, while the main village churches were at least still intact, this was not the case as far as the casazze were concerned. Many had been deconsecrated and either sold off or taken over by the municipal authorities and converted for use as schools, town halls, or function rooms. In these cases, the confréries were effectively homeless and so more dependent on the disposition of the local priest than they would have been in the past.

$<1>$ Case Studies: The Path to Revival

The following brief case studies illustrate the range of circumstances that have led to the revival of individual confraternities and the processes involved in reacquiring musical repertories. The next section of my discussion will then explore in greater detail the kinds of obstacles that have had to be negotiated in carving a new place for the confraternities in the church.

During the summer of 2002 I attended several of the weekly rehearsals of two confraternities that had recently been re-launched, based at the villages of Costa and 
Speloncato in the Balagne. In both cases, crucial input had been provided by Santu Massiani and Antoine-Jean Luiggi from the nearby region of the Giunssani, where they had played key roles not only in the revival of their own confraternity but also in the project of reconstructing the half-forgotten polyphonic mass settings of the villages of Pioggiola and Olmi Cappella. ${ }^{\text {ix }}$ The confrérie of Notre Dame du Rosaire at Costa includes members from the neighboring villages of Occhjatana, Palasca, Ville di Paraso, and Belgodère (all part of the pieve of Tuani). According to one of the village elders, the original confrérie at Costa was established in 1773 and continued to function up until the beginning of the First World War; it had been reactivated in 1921 but had once again fallen into disuse in 1943. The confréries of the other villages had suffered similar fates. The motivation for creating a new inter-commune confrérie was not only a concern for viable numbers (Costa, the smallest commune in the Balagne, has a total population of around fifty) but also the desire to bring together the young people of the different villages. Costa was chosen as host for the practical reason that its casazza, which is attached to the newer building that now functions as the main church, had been left untouched whereas the casazze of the other villages had been deconsecrated and put to other uses (a community hall, an exhibition space, a bar, and a bakery).

At the time of my visits, the confrérie had approximately twenty members who had been building up their musical repertory for the past four years. [INSERT OWM COMPUTER ICON HERE - plate 5] They were now in the process of recuperating and reconstructing their own polyphonic mass, having begun by learning parts of mass settings from other villages in the Balagne and settling on the Kyrie of Moncale, the Sanctus of Pioggiola, and the Agnus Dei of Olmi Cappella (all recently reconstructed) as their preferred combination. I was able to attend the first marriage to have been celebrated in the village for twenty-five years, with the confrérie singing the mass. Earlier that year, on Maundy Thursday, they had sung the Office of the Tenebrae for the first time in sixty years. 
The oldest members do not normally sing but attend every rehearsal nonetheless. They keenly follow the progress of the junior members, their eyes lighting up when the youngest takes a solo. Philippe Costa (seventy-nine years old at the time of our interview) talked of how, as a boy, he heard the confrérie singing "all the time," and described his joy at seeing the church doors open and the confrérie walk out singing after so many years of silence: "To see that which used to exist brought to life again is an extraordinary return to the past, extraordinary. ... There is nothing more beautiful. That brings back the soul, it brings back life, and hope too" (Philippe Costa, interview, July 5, 2002, Costa).

The confrérie of San' Antone Abbate in Speloncato was reinaugurated in 2001. In this case, the revival of the confrérie was predated by the revival of the mass and other liturgical material. In the 1980s, the Reverend Squarcioni (then the village priest) and Jean-Dominique Poli (one of the singers in the revived confraternity) had visited the former canon, Michel Colombani, and his brother Antoine, former cantor and prieur of the confrérie, in their place of retirement and had recorded what they remembered of the mass as it used to be sung in the village. Like the masses of Pioggiola and Olmi Cappella, this mass then also underwent a process of reconstruction. According to Poli's account, at this time there was already talk of restarting the confrérie but the most pressing thing was to "find" the Speloncato repertory. It was only in 2001 that the time was finally ripe. The confrérie at Costa had already been launched and its members had on occasion come to Speloncato to sing. Seeing a confrérie in the church again had strengthened the desire for the village to have its own confrérie that would sing the repertory specific to Speloncato (Jean-Dominique Poli, interview, July 14, 2002, Speloncato). Together with Pierre Dottori (a strong singer and the confrérie's new prieur), Poli also visited the Phonothèque in Corte to listen to the recordings made by Félix Quilici in Speloncato in the late 1940s. 
Of the sixteen regular members that made up the confrérie in 2002, three had been confrères in their youth. Three of the current members were designated as "singers," with the others "supporting"; they had all learnt the material, which they had been working on for just one year, from scratch. Their repertoire now consisted of the messe des vivants and messe des morts, the Office of the Dead, Office of the Tenebrae, Offiziu di i Priori (for the investiture of a new prieur), the Chemin de Croix, songs for Christmas and Easter, and other processional songs. The mass itself, they explained, used to be sung not by the confrérie but by the village cantors, dressed in civilian clothes. Since there are no longer any cantors, however, it is now the confrères who sing the mass for the fêtes patronales, other special feast days, and funerals (but not the ordinary Sunday mass, which happens once a fortnight). Parallel to the confrérie, a cultural association —also called San' Antone — was established as a secular arm that would be eligible to apply for funding. ${ }^{\mathrm{x}}$ It is this association that now takes responsibility for the organisation of festivals and that has raised funds for initiatives such as the restoration of the bells in the casazza.

If in some villages those involved with renewing the tradition are aided by their recollections - however faint — of having heard parts of the repertory sung in their youth, in others no such memory remains. This is the case in Lumio, another village in the Balagne, where by the 1990s the Dumont mass (sung in unison) was so well established that, in Max Vuillamier's words, "For the old people in the village, the village mass was, in effect, the mass of Dumont" (Max Vuillamier, interview, July 6, 2002, Lumio). ${ }^{\text {xi }}$ One of the difficulties facing Vuillamier in his role as prieur and teacher was that, as far as the present singers were concerned, he was their only model. Vuillamier himself, who had previously served as sousprieur at Calenzana, is in fact from Calvi. He is also a long-standing member of the group A Filetta, whose repertory includes items from the sacred music heritage of the Balagne. When he joined his new wife in Lumio, he was asked to help revive the confrérie, which had fallen 
into disuse in the 1940s. Following its re-establishment in 1993, he spent the first year teaching his fellow confrères the messe des vivants, offering them what he already knew. As in Costa, they chose the combination of pieces that most appealed to them while drawing primarily on reconstructed material from the nearby village of Moncale, which had been translated into Corsican. In the case of the messe des morts, they opted for what was sung in Calvi. They also learned the processional songs for Holy Week, building up their repertory year by year. [INSERT OWM COMPUTER ICON HERE -plate 6]

On the east coast of the island, the Cunfraterna di San-Bastianu of Santa Maria Poggio - dormant since 1941 — was reconstituted in 1992 in association with the local scola di cantu, which had existed since 1987. In this case the confrérie initially continued to sing the mass of Rusio that its members had already learned in the scola di cantu. Presently, they began work on the mass setting that used to be sung in their own village with the help of old recordings that had now come to light: one-of the messe des vivants sung in polyphony for the Feast of the Assumption, together with a version of the Libera Me-made in 1965 by the village priest, Abbé Paul Filippi, and the other featuring a sole surviving singer, Etienne Contri, singing the middle (melody) voice of both the messe des vivants and the messe des morts. The local setting of the messe des vivants was sung again for the first time in 1999. When I interviewed the young prieur, Charles Contri, in 2002, he and his fellow singers had worked their way through half of the messe des morts, painstakingly reconstituting the bass and top voices on the basis of the way in which the parts were constructed for the messe des vivants. The confrérie had also assumed responsibility for processions, since the priest did not have time to organize these.

Each of the examples above concerns a small village that is relatively self-contained and has the potential, at least, to make collective decisions about its own affairs while also having to contend with limited resources (both financial and human). An interesting contrast 
is offered by the coastal city of Ajaccio, the island's administrative capital, which by the end of the twentieth century had a population of over 60,000 . Here, grassroots-style initiatives have shared the stage with projects instigated by the municipal authorities and designed to showcase the city's cultural assets in a more mediated format. For a period of thirty years following the Second World War, there had been no active confrérie in the city and virtually all trace of the former repertory had long since been lost. The tide began to turn when, in the 1970s, the group Canta u Populu Corsu (leading lights of the musical face of the riacquistu) set a precedent for a return to tradition by forming the Confraterna (or Paladini) di L'Immaculata and singing a weekly mass - a mixture of the settings of Sermano and Rusio, with the texts said in Corsican — at the Oratory of St. Roch. In a separate initiative Christian and Jean-Jacques Andreani, members of the group Caramusa, began to work with the prieurs of the confréries of Bonifacio to help motivate the younger members to preserve the local repertory. Together with fellow Caramusa member Joseph Figarelli, the Andreani brothers subsequently joined forces with the revived confrérie of St. Jean Baptiste based at the Cathedral in Ajaccio, establishing regular weekly meetings at which they taught the mass. Caramusa, like other Corsican groups at that time, was more concerned with musical research, documentation, and preservation than with courting personal fame and fortune, and the efforts they invested in the confraternities were in keeping with their conviction that "the songs should not just be for the stage" (Figarelli pers. com. 1995). The mass that was being sung by St. Jean Baptiste when I frequented their rehearsals in the mid-1990s included parts of the mass of Rusio and an Agnus Dei derived from that of Olmi Cappella. They had also adopted other material from the Bonifacio confréries. When they began to sing the mass for feast days, this role had to be shared with the well-established mixed cathedral choir that sings predominantly in French. At the same time, they sang once a month for a mass that was said in Corsican. 
Meanwhile, another Ajaccio confrérie dedicated to St. Erasmus had been specially reconstituted for the celebration of the Madunnuccia (Notre-Dame de la Miséricorde) in 1992, the year of the fifth centenary of the founding of the city. In preparation for the festivities surrounding what was primarily a civic occasion, the Ajaccio authorities were instrumental in encouraging the fishermen and sailors to re-establish the confrérie and in providing funds for new costumes and processional props. [INSERT OWM COMPUTER ICON HERE -plate 7] The event was filmed by the television channel France 3 Corse and later released on video ("A Madunnuccia”: La Vierge aux Quatre Miracles, 1993). While the more public profile enjoyed by the confréries as a result of this kind of promotion might have helped to attract more young people to their ranks, many were at pains to avoid what they saw as manipulation and were critical of those who compromised themselves by consenting to play the part of actors in what is little more than a colorful folkloric spectacle. In the case of St. Erasmus, some of its new members did subsequently express an interest in singing, having initially been content to specialize in carrying the heavy and unwieldy statues in processions. At this point they were joined by members of the group Cinqui Sò, who for a short period in the 1990s sang the mass for feast days.

$<1>$ Contested Spaces: The Play of Power and the Art of Compromise

In the early twenty-first century, the confraternities occupy an interesting pivotal point between religious, cultural, and socio-political concerns, constituting what Marcel Pérès has described as "a multiplicity of zones of tolerance on the borderline between the clergy and the population at large" (1997: 10). Part of their appeal to the younger generation can be attributed to their status as relatively autonomous bodies rooted in local communities, as well as repositories of ancient knowledge. Polyphonic singing is now generally viewed as central 
to their role, and their archaic-sounding liturgical and paraliturgical repertories as a vital component of local identity. Some, however, struggle to hold their ground in the face of the very different ideas held by some priests - in line with their training in the "French school" and their espousal of Vatican II ideologies - about what should go on in the churches under their care. The musical and ritual activities of the confraternities tend therefore to be equated with local, indigenous, popular, and democratic practice, which is set in opposition to national, top-down practice as dictated by the ecclesiastical authorities, and indeed to the global uniformity that Vatican II pointed towards.

These points of conflict are by no means unique to Corsica. The growth in popular religious practice across Europe has in many places been accompanied by an increase in anticlericalism. As Badone (1990) and others have pointed out, anticlericalism in this context results not from a rejection of Christianity but from the conviction that the Church itself falls short of its responsibilities, with the people showing a greater respect for Christian doctrine than do the priests, who may be portrayed as robbing the people of their religion. Some writers have pointed to a tenacious belief that religious practices are a divine expression of eternal truths, and that even the Pope does not have the right to change them (see Bahar 1990 and Brandes 1990). Opposition to religious reform can also be seen as part of the broader resistance to modernization. Given the extent to which, in many parts of the world, Catholicism has become ingrained as part of local culture, it is not surprising to find that loyalty to tradition is retained at a "folk" level as what was formerly enforced by the highest authorities is now discarded by those same authorities. In Corsica, the tendency to view reforms as a threat to the cultural heritage was heightened in the climate of the riacquistu with its reification of tradition and patrimoine.

Questions of ideology, local politics, and aesthetics intersect at the site of these struggles, with the "old" sounds that index birthright and ownership of particular spaces also 
being considered "the most beautiful." A particular bone of contention has been the inclusion of the Libera Me and Dies Irae sequences in the requiem mass. Since Vatican II, the notions of a vengeful and jealous God embedded in these texts have been deemed antithetical to the project of the salvation of souls, and, as elsewhere, the Bishop of Corsica has espoused the view that they should no longer be sung. The confraternities, however, have argued passionately for their right to continue to sing these songs, just as they have always done, because they are "the most beautiful" songs they have and because they "fulfil a need"unlike the approved alternative, "Sur le Seuil de ta Maison," which typifies the supposedly accessible type of material introduced post-Vatican II to promote increased participation by the whole congregation. Tales are sometimes told of funerals where members of the confraternity or of the old independent singing ensembles, dressed in civilian clothes, have bided their time before leaping to the coffin to sing the absolution before the priest could stop them.

In the Corsican case, as noted earlier, additional complexities have been introduced since the contest is also a gendered and linguistic one, with the (untempered, unmeasured) male voices of the confraternities singing in Latin and old Tuscan competing with the (tempered, measured) female voices of the "modern" choirs singing in French. Understandably, women's choirs have seen no reason why they should relinquish their own place just because the parish confraternity has been resurrected. In some cases this has led to tensions over whose prerogative it is to sing for a particular occasion, with the women looking around anxiously for signs that "the men" are planning to sing, while the latter note the (for them) ominous arrival of the harmonium player. On one such occasion (in the mid1990s) where confrères and choir members from neighboring villages had joined together to celebrate a special feast day, I watched as the harmonium player raised her fingers above the keyboard, only to be beaten to the post by "the men" who, on a frantic signal given by one of 
the prieurs, launched into a hearty rendition of "Perdono mio Dio." Arriving at the end of the thirty-fifth and final verse, they cast about urgently for a clue as to what they should do next - hesitating just long enough for the long-suspended fingers of the harmonium player to finally make their move and allow the women to launch into an equally spirited rendition of the French canticle they had prepared. The prieur who had led the "Perdono" nobly accepted defeat and went over to join them.

It is, of course, important not to generalize about the positions adopted or to overstate their oppositional character. Inevitably, any change to an established routine will take time to settle, with further adjustments being made to suit local circumstances. Some priests go further than others in recognising the need to accommodate the forms of expression chosen by the people, and some actively support and encourage the confraternities. For their part, many of the prieurs acknowledge that simply to dismiss the women's choirs and their accompanists that may have been in place for fifty years or more is not a realistic option. In many places, therefore, by the first decade of the twenty-first century both parties had settled into a state of cooperation rather than competition. In one village, the confrères might sing the mass once a month and, at other times, join in singing French canticles with the women. In another, the women's chorale might sing the Introit and Offertory on occasions when the men were singing the Kyrie, Sanctus, and Agnus Dei, for example. In Calvi, the messe des morts might be accompanied on the harmonium when the accompanist was present, but sung unaccompanied and in polyphony when she was not. For Calvi's major feasts, elements in Latin, French, and Corsican might be combined in a format that had been agreed in advance. Meanwhile, some of the women's choirs were themselves suffering from an aging and declining membership base.

This spirit of greater tolerance was applauded and encouraged in the Actes du Synode of the Church of Corsica for the year 2000. The section "La Place des Confréries dans 
L'Église," which was the outcome of two meetings between the then bishop, Mgr Lacrampe, and representatives of the island's confraternities in 1999 and 2000, focuses on four main themes: the presence of the confraternities in the local church, the place of sacred song (le chant sacré) in the Vatican II liturgy, the statutes of the confraternities, and the relationship between the confraternities and the diocese. The document refers to "cases of conflict ... between the celebrating priest and confréries ... about the use of song" occurring "when requests for songs in Latin or in Corsican have been made at the last moment, barely minutes before the start of a celebration" (Église de Corse 2000: 99). It is stressed that services (including weddings and funerals) should be planned well in advance and that all concerned must remember that "it is Christ we are celebrating" and that all "ideological combat" must therefore be avoided. It is also noted that the liturgical reforms of Vatican II did not outlaw Latin, even if they expressed a preference for using the vernacular, and in fact leave ample flexibility regarding linguistic usage; a list is given of parts of the liturgy for which the Corsican language may be used.

The church is certainly aware of the fragility of its own position in an increasingly secular age where it no longer enjoys absolute power, realizing that over-enthusiastic opposition to popular activity and local usage will only result in further alienation. In Corsica, it also recognizes that confraternity activity can to some extent fill the gap left by the acute shortage of priests. In the year 2000, the entire island was served by only sixty-one priests (half the number of twenty years previously), aided in their endeavours by twenty-five monks (Casta 2001: 84). It is not unusual for a single priest to serve a dozen villages. Consequently, many villages no longer have a weekly mass, and the priest is unable to preside over every procession. In extremis, a service might have to go ahead - in reduced form-without the priest, or else be cancelled. Those rites that may be conducted by the confrérie alone therefore play a crucial part in keeping religious observance alive. It is also the case that the increase in 
confrérie activity has led to more people attending religions celebrations in order to support the confrérie.

The way in which the position of the confraternities has evolved also sheds interesting light on the theme of missionization, challenging normative assumptions about the balance of power and about the relationship between conservative and progressive stances. If in earlier times the confraternities were harnessed as part of a top-down project of evangelization, in their contemporary form they can be seen to be enacting a mission to preserve tradition and protect the church against its own reforms, while local congregations might be seen to have moved from a position of submission to one of greater self-empowerment. The confraternities continue to function as intermediaries between the ecclesiastical authorities and local communities, but with the direction to some extent reversed.

$<1>$ The Spirit of Community

Overall, the focus on singing has increased as the social function of the confraternities in strictly material terms has lessened. Song provides a motive for regular meetings, as well as serving as the raw material that facilitates the initiation of the individual into a collaborative endeavour. Rehearsals have a vital social and community dimension, in addition to a musical one, and if singing is not so central to a confraternity's activities, then its members have fewer occasions to meet. As far as the confrères at Speloncato are concerned, it would be impossible to keep the confraternity afloat without the musical dimension: "It is thanks to the songs", says Santu Massiani, "that we are obliged to work together" (Santu Massiani, interview, June 30, 2002, Olmi Cappella). Polyphonic singing in particular is predicated on the ability to listen to others. But what needs to be heard, says Pierre Bertoni in Calvi, is not simply the correct harmony but the "communal life" that underpins it: "beyond the meaning of the 
words, there is this sense of life, this sense of the collectivity" (Pierre Bertoni, interview, July 5, 2002, Calvi). In this respect, the sense of place is again important. Bertoni continues: "You can't content yourself with just singing a beautiful song, just like that, with a beautiful voice. You have to know the secret language of the song from here, from where you are. You have to have the keys. And it's not only notes of music. . . It's that which passes, the sense that passes that is important" (ibid).

Many are keen to stress, however, that while singing may act as the glue that binds the confrérie together and is central to its public visibility, belonging to the confraternity is about more than this. Having brought its members together to rehearse the repertory, the confrérie becomes a forum where the different generations interact. The young learn to respect their elders and better understand their concerns. Equally, Santu Massiani points out, when an eighteen-year-old speaks, his voice carries as much weight as that of an older man. "The young people are attracted by the songs, by this life of fraternity," explains Philippe Costa. "We learn what we are, we share our troubles, our worries, our joys ..." (Costa interview 2002). Working together on the music requires and teaches tolerance. It also demands wisdom and sensitivity on the part of the prieur. One speaker describes polyphonic singing as "a great task of diplomacy." The principles of tolerance and diplomacy often take precedence over concerns for artistic perfection. When singing the mass, for example, it is not always easy to restrict the singing to one voice per part. As one prieur explained, there are often more people who want to sing and this does not always work so well, but "we are not on the stage. It's a mass. Whoever wants to sing can sing" (Vuillamier interview 2002). At the same time, a younger singer who is a vital part of the driving force behind a confrérie but appears overfond of the limelight and sings more forcefully than the others may need to be gently reined in. 
In the case of the Cunfraterna di a pieve di a Serra - another new inter-parish confrérie drawing its members from fourteen villages in the region of Aleria-the traditions of the villages had never been lost. Following the decline of the original village confréries in the 1950s, the repertory had been maintained by a small group of cantors. Prieur Jean-Charles Adami points out that, if singing and animating the mass had been the main goal, then there would have been no need to revive the confrérie. What had disappeared and served as the impulse for the re-creation of the confrérie is what Adami refers to as "the fraternal structure." "It's a more profound experience," he says, "a sharing of life, a whole dimension that is human, religious and spiritual" (Charles Adami, interview, July 24, 2002, Aleria). For Adami, the confrérie structure also represents a way of responding to the difficulties of modern life, in particular the pressures imposed by the culture of individuality: "It counteracts everything in the world today that is perverse and negative." In this sense, the tradition they are reviving is not simply "passif" (looking back to the past), as some detractors would claim. It is "anchored in the present. It engages with the difficulties of today and not the difficulties of yesterday" (ibid.). For Pierre Bertoni, it is the prieur's responsibility to ensure that the confrères "know why they are there." "They are there for themselves," he says, "they are there for the rite, for the gospel. But they are also there for the confrérie, for the equilibrium of the confrérie." If they do not understand this, then they are merely engaging in ritual for ritual's sake (Bertoni interview 2002). ${ }^{\text {ii }}$

$<1>$ Bearing Witness

In the early twenty-first century, the sacred setting is one of the main arenas in which traditional music retains its primary function as part of people's everyday lives. In the summer months, the rituals of the confraternities and the paraphernalia of tourist life vie for 
space in the narrow streets of coastal towns such as Calvi or its southern counterpart, Bonfacio. The traffic is halted and bemused tourists look on as the prieur leading the procession of the Assumption or St. Barthélemy (San Bartolu) pushes through the racks of designer clothes and beachwear that spill out into the streets. [INSERT OWM COMPUTER ICON HERE -plate 8]

It is thanks to the confraternities that the "old" sounds continue to resonate in the churches and streets of many of Corsica's towns and villages. Precious musical repertories have been salvaged and given new life, offering a valuable insight — through the window of the twenty-first century - into a vibrant world of popular religious expression that in many places has long since died out. As this study has shown, however, this is not the only reason for the confréries' significance. Over and above the "archaic" structural and stylistic principles preserved in their repertories, they promote an alternative aesthetic of musicmaking informed by the communal, democratic ethic that underpins confraternity life as a whole, where participation is more important than perfection, and the collective is more important than the individual. When I first began to visit Corsica in the early 1990s, there was a fear that the group phenomenon might take over, that musical practice would become ever more professionalized, commodified, and commercialized, and that it was this path that would attract aspiring singers from the younger generation. In the event, however, many young men have embraced the opportunity offered by confraternity membership to be part of local animation while expressing a newfound sense of identity in the context of the traditional heritage, and the songs have played an instrumental role in drawing young people into the church. Initiation into the art of singing has also served as part of a broader initiation into the art of living in community. When Santu Massiani says, "we are here to bear witness," he is referring not only to the Christian faith. The Corsican confraternities also bear witness to the 
island's history, to the local community, its traditions, and its cultural heritage, and to the human spirit.

References

“A Madunnuccia”: La Vierge aux Quatre Miracles. 1993. France 3 Corse.

Badone, Ellen. 1990. "Breton Folklore of Anticlericalism.” In Religious Orthodoxy and Popular Faith in European Society, edited by Ellen Badone. Princeton: Princeton University Press.

Bithell, Caroline. 2006. "Musical Archaeologists: The Revival and Reconstruction of Polyphonic Masses in Corsica.” In The Past in Music, edited by Caroline Bithell: special issue of Ethnomusicology Forum, vol. 15, no.1: 113-145.

Behar, Ruth. 1990. "The Struggle for the Church: Popular Anticlericalism and Religiosity in Post-Franco Spain.” In Religious Orthodoxy and Popular Faith in European Society, edited by Ellen Badone. Princeton: Princeton University Press.

Boissevain, Jeremy, ed. 1992. Revitalizing European Rituals. London and New York: Routledge.

Brandes, Stanley. 1990. "Conclusion: Reflections on the Study of Religious Orthodoxy and Popular Faith in Europe.” In Religious Orthodoxy and Popular Faith in European Society, edited by Ellen Badone. Princeton: Princeton University Press.

Carrington, Dorothy. 1984. Granite Island: A Portrait of Corsica. London: Penguin.

Casanova, Abbé S.-B. 1931. Histoire de L'Église de Corse: des origines à la révolte de 1729. Ajaccio: Imprimerie Typographique. 
Casta, Michel. 2001. "Des catholiques corses. XIXe-XXe siècles.” In Corsica Christiana: 2000 Ans de Christianisme, Musée de la Corse, 72-86. Ajaccio: Collectivité Territoriale de la Corse.

De Moro, Gianni. 2001. “Confraternite corse e liguri: due modelli a confronto.” In Corsica Christiana: 2000 Ans de Christianisme, Musée de la Corse, 276-290. Ajaccio:

Collectivité Territoriale de la Corse.

Mattei, Nicolas. 2000. "Essai sur le devenir des confréries corses (XVIIe-XXe siècles)." Strade (Travaux du Centre d'Études Corses),no. 8: 15-27. . 2001. "Une communauté et ses confréries, Speloncato.” In Corsica Christiana: 2000 Ans de Christianisme, Musée de la Corse, 292-304. Ajaccio: Collectivité Territoriale de la Corse.

Église de Corse. 2000. Les Actes du Synode. Ajaccio: Église de Corse.

Pérès, Marcel. 1996. "Préface.” In Le chant religieux corse: état, comparaisons, perspectives, edited by Marcel Pérès, 7-14. Bar-le-Duc: Éditions Créaphis. 1997. Liner notes to the CD Laude: Cunfraterna di a pieve di a Serra. Albiana \& Casa.

Polacci, Daniel. 1997. "Histoire de la Confrérie San Carlu de Carbuccia." Self-produced pamphlet.

Römer, Markus. 1983. Schriftliche und mündliche Traditionen geistlicher Gesänge auf Korsika. Wiesbaden: Franz Steiner Verlag.

\footnotetext{
${ }^{\mathrm{i}}$ I am grateful to the British Academy for contributing to my original doctoral fieldwork in Corsica in 1994-1995 and for the later award of a Small Research Grant that allowed me to devote the summer of 2002 to a more focused investigation into the reconstruction and revival of polyphonic sacred music repertoires.
} 
${ }^{\mathrm{ii}}$ In the interests of consistency with the literature and interviews in the French language on which this chapter draws, I use the French terms confrérie(s) and confrère(s) in my own commentary. The Corsican appellations are used when these occur in my source. Alternative designations for the confrérie occasionally found in the historical literature are cumpagnia, università, sodalità, and congregazione (see Mattei 2000).

iii The majority of the village casazze were built in the late fifteenth and early sixteenth centuries. The fact that some are older than the main church, together with the surprisingly large scale on which many are built, is explained by the fact that they had often served as the original village church but had been taken over by the confrérie when a newer church was built by one of the noble families. Other casazze were purpose-built by the confréries themselves with the help of donations, often on land gifted to them by rich families. ${ }^{\text {iv }}$ Accounts relating to the confrérie of Santa Croce in Speloncato include grain and wax as well as money. The annual subscription in the seventeenth century was 20 soldi for men and 40 soldi for women, plus "un bacino di grano" every August (Mattei 2001: 301, 299). The statutes also stipulate a minimum reserve of both cash and wax that should be kept in the account at all times.

"Allowable reasons for non-attendance are listed, including "vendetta," with a fine of $0.2 \mathrm{~L}$ for disobedience (Mattei 2001: 296-300).

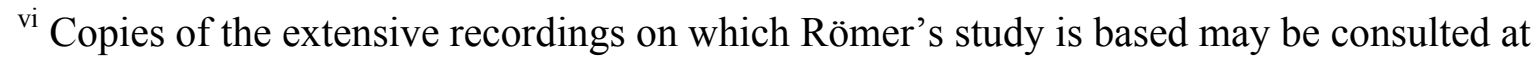
the Phonothèque of the Musée de la Corse in Corte.

vii The Franciscan order appears to have flourished in Corsica more than anywhere else in Europe. By the end of the thirteenth century the Franciscans had eight monasteries on the island and by the census of 1769 there were sixty-three (Carrington 1984: 111), with an estimated 1,000 of the 1,114 monks then resident on Corsica being Franciscans (Casanova 1931: 351). 
viii Sauli's extensive correspondence with Borromeo represents a valuable source of information regarding the state of the church in Corsica in the period immediately following the Council of Trent.

${ }^{\text {ix }}$ For an account of this project, see Bithell 2006.

${ }^{\mathrm{x}}$ In the official register, the objective of the association is given as "mutual aid, solidarity, support of initiatives to maintain the traditions of the village, the customs; to organize cultural manifestations with the aim of safeguarding village memory such as, for example, the festival of the pig and carnival."

${ }^{\mathrm{xi}}$ Vuillamier adds that the mass had been "corsisized" and that the villagers were not necessarily aware that the same mass was also sung in other places.

xii The Actes du Synode 2000, in stressing the primary role of the confraternities in terms of evangelization, notes that the church and the confraternities are in agreement that "there can be no question of admitting a new confrère simply because he has a good voice" if he has "no desire to come to know Jesus Christ" (Église de Corse 2000: 98). 